\title{
FORMULASI BARU EPISTEMOLOGI FIQH PEREMPUAN
}

\author{
M. Noor Harisudin \\ (Institut Agama Islam Negeri (IAIN) Jember Jl. Mataram No. 1 Mangli, \\ Kaliwates, Jember.Email: memsudinstainjember@gmail.com)
}

\begin{abstract}
Abstrak:
Secara de facto, fiqh kita adalah fiqh yang memarginalkan perempuan dan tidak kritis terhadap ketimpangan sosial yang terjadi pada perempuan. Sistem sosial tidak lagi menjadi patriarkis, namun lebih berdasar kesetaraan gender. Karenanya fiqh yang lebih ramah dan lebih peduli terhadap perempuan harus diwujudkan. Fiqh ini harus dirancang dengan epistemologi yang berbasis pada kemaslahatan perempuan. Artikel ini mengusulkan formulasi baru menuju epistemologi fiqh perempuan dan atau ushul fiqh baru yang benarbenar ramah terhadap perempuan. Artikel ini merekomendasikan bahwa formasi hukum Islam yang cenderung abai terhadap perempuan adalah sebuah sine qua none. Reformasi itu harus dirangkai melalui ranah epistemologis, metodologinya, dan selanjutnya pada produk fiqh perempuannya. Ketiganya berjalan seiring dengan inti utamanya yaitu memartabatkan perempuan. Dengan demikian, produk fiqh perempuan yang lebih sesuai dengan perubahan tempat dan zaman akan menjadi kenyataan.
\end{abstract}

\begin{abstract}
:
Though the world has changed, factually, our figh marginalizes women and not critical of social inequality among women. The social system is no longer a patriarchal, but it's more based on gender equality. Therefore, the existence of more moderat and friendly fiqh for women should be realized. Figh should be designed with epistemology based on the mashlahah of women. This article proposes a new formulation towards epistemology of women figh and/ or new ushul figh which are really friendly towards women. This article recommends that the formation of Islamic law which is tends to neglect women is a sine qua none. Reform must be arranged through the epistemological realm, methodology, and product of women figh. All the three go hand in hand with its main core to potitioning the women in equal place. Thus, product of women figh that is better suited to the changing places and times will become a true.
\end{abstract}

al-1hkâm Vol.10 No.2 Desember 2015

DOI: http://dx.doi.org/10.19105/ihkam.v10i2.735 


\section{Key Words:}

Patriarkhi, Fiqh Perempuan, Epistemologi, Ushul Fiqh

\section{Pendahuluan}

Kendati pada abad XXI ini terjadi perubahan sosial, namun fiqh sebagai sebuah disiplin ilmu ${ }^{1}$ masih menunjukkan corak lamanya. Sebagai contoh, pergeseran sistem sosial yang semula bercorak patriarkis dan kemudian menjadi lebih terbuka pada isu-isu kesetaraan gender nyatanya belum diimbangi dengan fiqh baru yang lebih ramah terhadap perempuan. Fiqh yang ada masih merupakan fiqh warisan masa lalu dan tidak up date terhadap perkembangan sosial budaya di masa kini.

Diktum bahwa fiqh harus mengikuti perubahan merujuk pada kaidah taghayyur al-ahkâm bi taghayyur al-azminah wa al-amkinah (perubahan hukum seiring dengan perubahan ruang dan waktu) sangat sesuai dengan gerak fiqh yang dinamis. ${ }^{2}$ Pun demikian dengan epistemologi fiqh yang juga semestinya bergerak dinamis berdialektika dengan ruang dan waktu. Epistemologi fiqh harus diperbaharui terus menerus sesuai dengan perkembangan ruang dan perjalananan waktu. Demikian juga, fatwa-fatwa hukum Islam masa lampau harus diteliti ulang kesesuaiannya dan relevansinya dengan masa sekarang.

Beberapa ulama telah memberikan acuan yang jelas mengenai fiqh dan fatwa yang bisa berubah ini. Menurut Ibn al-Qayim alJawziyah, sikap jumud dengan terus bertahan dengan nukilannukilan adalah kesesatan dalam agama dan ketidakpahaman terhadap maksud dan tujuan para ulama di masa lampau. ${ }^{3}$ Ibnu 'Âbidîn mengungkapkan hal senada. Menurutnya, mufti tidak boleh puas dengan (hanya menerima) apa yang dinukil dalam kitab-kitab zhâhir al-riwâyah, tanpa memperhatikan zaman dan manusia zaman itu. Kalau ini terjadi, maka akan banyak hak yang ia korbankan dan mudaratnya lebih besar dari manfaatnya."4

${ }^{1}$ MN. Harisudin, Ilmu Ushul Figh I (Jember: STAIN Jember Press, 2014),2.

2 Zakariyâ al-Anshâri, Ghâyah al-Wushûl Syarh Lubb al-Wushûl (Semarang: Maktabah al-Alawiyah t.th.), 65.

3 Ibn al-Qayyim al-Jawziyah, I'lâm al-Muwaqqi'în 'an Rabb al'Âlamîn, Juz III Cet II (Beirut: Dar al-Kutub al-'Ilmiyah, 1993-1414 H),. 99.

4 Ibn 'Âbidîn, Nasyr al-'Urf, Juz II, (Beirut: Dar al-Fikr, tt), 113. 
Jika dengan pembaruan ini epistemologi fiqh perempuan berubah, maka demikian ini merupakan sebuah keniscayaan historis. Fiqh dan fatwa bisa berubah, demikian juga dengan epistemologi fiqh perempuan juga dapat berubah. Epistemologi fiqh yang dimaksud di sini, meminjam bahasa Mohammed Arkoun, adalah sebuah disiplin ilmu ushul fiqh yang juga dikenal sebagai teori hukum Islam. ${ }^{5}$ Bagaimanapun, ushul fiqh sebagaimana pandangan Amin Abdullah, merupakan metodologi terpenting yang ditemukan oleh dunia pemikiran Islam. ${ }^{6}$ Pada tubuh ushul fiqh ini, fiqh diproduk dan diramu sedemikian rupa menjadi metodologi istinbâth hukum paling otoritatif. Dengan pelbagai metodenya, ushul fiqh telah membuat produk fiqh sangat melimpah.

Tulisan berikut ini berpretensi lebih jauh mengelaborasi formula baru epistemologi fiqh perempuan dan atau ushul fiqh baru yang benar-benar ramah terhadap perempuan.

\section{Definisi Fiqh Perempuan}

Secara etimologi, fiqh perempuan juga sering disebut dengan figh al-nisấ. Fiqh berasal dari kata faqiha-yafqahu-fighan yang berarti pemahaman. Sementara itu, fiqh secara istilah berarti “ilmu tentang hukum syara' yang bersifat praktis yang digali dari dalil-dalil yang terperinci."7

Nisấ secara etimologi berarti perempuan. Nisấ adalah bentuk jamak dari mar'ah yang berarti perempuan yang sudah matang atau dewasa. ${ }^{8}$ Istilah lain yang digunakan untuk perempuan adalah imra'ah. Imra'ah berasal dari kata mir'ah yang artinya cermin. Ini berarti bahwa pada umumnya perempuan suka bercermin atau suka menghias di depan cermin. Term imra'ah ini lebih tepat digunakan

\footnotetext{
${ }^{5}$ Mohammed Arkoun, The Concept of Authority in Islamic Thought, dalam ed. Klaus Ferdinand and Mehdi Mozaffari, "Islam: State and Society", (London: Curzon Press, 1998), 62.

6 M. Amin Abdullah, "Paradigma Alternatif Pe-ngembangan Ushul Fiqh dan Dampaknya pada Fiqh Kontemporer", dalam Ainur Rofiq (ed), Mazhab Yogya: Menggagas Paradigma Ushul Figh Kontemporer, (Yogyakarta: Ar-Ruzz, 2002), 117.

7 'Abd al-Wahhâb Khallâf, 'Ilm Ushûl al-Fiqh (Mesir: Al-Haromain, 2004), 12. Muhammad Abû Zahrah, Ushûl al-Figh, (Beirut: Dar al-Fikr al-Araby, 1957), 6.

8 Ibn Manzur, Lisân al-'Arab, jilid XV, (Kairo: Dar al-Hadis, 2003), 321. Bandingkan dengan al-Ra-ghib al-Isfahânî, Mu'jam Mufradât Alfazh al-Qur'ân, (Kairo: Dar al-Kitab, al-Araby, tt), 513.
} 
untuk menyebut perempuan yang masih gadis, perempuan muda yang sudah bersuami dan janda karena mereka suka menghias diri. ${ }^{9}$

Dalam kamus bahasa Indonesia, perempuan diartikan sebagai perempuan dewasa, yang dapat menstruasi, hamil dan melahirkan anak. ${ }^{10}$ Adil Athi Abdullah, sebagaimana dikutip Aisyah Ismail, mengatakan bahwa perempuan adalah makhluk Allah Swt. yang mulia pasangan lelaki, yang dilebihkan Allah Swt. dengan ciri kehamilan, melahirkan, dan menyusui serta ketajaman kejiwaan seperti kasih sayang yang tinggi, kesabaran dalam mendidik anak serta kelembutan jiwa. ${ }^{11}$

Walhasil, fiqh perempuan adalah ilmu tentang hukum syara' yang berkai-tan dengan perempuan yang bersifat praktis dan digali dari dalil-dalil yang terperinci. Aisyah Ismail menyebut fiqh perempuan setidaknya memuat dua hal. Pertama, hukum-hukum praktis yang berkaitan dengan perempuan. Kedua, dalil-dalil yang berkaitan dengan hukum praktis tersebut. Misalnya dalil tentang kepemimpinan perempuan. ${ }^{12}$

Pendapat Aisyah yang menyebut fiqh perempuan sebagai "hukum praktis perempuan" senada dengan pendapat Husein Muhammad. Seperti dinyatakan Muhammad, fiqh perempuan adalah bagian dari apa yang disebut oleh Abû Hanîfah sebagai figh asghar (fiqh kecil), sementara figh akbar adalah ilmu tentang usuluddin atau akidah. ${ }^{13}$ Fiqh perem-puan, dalam pandangan Muhammad, a-dalah masalah-masalah perempuan da-lam pandangan fiqh. ${ }^{14}$ Ini senada dengan penulis lain yang menyebut fiqh perem-puan sebagai hukumhukum fiqh yang berkaitan dengan perempuan. ${ }^{15}$

Sementara, pendapat Aisyah yang menyebut fiqh perempuan sebagai dalil-dalil perlu diklarifikasi lebih jauh. Karena dalil itu ada

\footnotetext{
${ }^{9}$ Ahmad Warson al-Munawwir, Kamus al-Munawwir Arab Indonesia, Edisi II, Cet. XXV (Surabaya: Pustaka Progresif, 1997), 1417.

10 Departemen Pendidikan dan Kebudayaan, Kamus Besar Bahasa Indonesia, Cet. III (Jakarta: Balai Pustaka, 1994), 27-28.

11 Aisyah Ismail, "Fiqh Perempuan Kekinian dan Keindonesian" dalam http://www.irwanlaw.com/artikel/dr-hj-aisyah-ismail/fiqh-perempuan-kekiniandan-ke-indonesiaan (diakses tanggal 18 Juni 2015)

12 Ibid.

13 Nuruzzaman et.al, Islam Agama Ramah Perempuan (Yogyakarta: LKiS, 2004), 109-110.

14 Ibid.

15 Umi Kulsum, Risalah Fiqh Wanita Lengkap (Surabaya: Cahaya Muliah, 2007), v.
} 
yang tafshîlî (terperinci) dan ada yang ijmâlî (global). ${ }^{16}$ Aisyah benar jika yang dimaksud adalah dalil terpe-rinci yang menunjuk pada salah satu dalil tertentu. Misalnya dalil tentang kepe-mimpinan perempuan. Namun, jika yang dimaksud adalah dalil ijmâlî, maka yang demikian kurang tepat karena dalil ijmâlî bukan domain fiqh, melainkan domain ushul fiqh.

Domain ushul fiqh adalah hukum kullî dan dalil ijmâlî.17 Hukum kullî merujuk pada hukum-hukum yang masih global dan belum menunjuk suatu ba-rang. Misalnya hukum wajib, sunah, haram, makruh dan mubah. Sementara, dalil ijmâlî merujuk pada dalil yang masih global seperti al-Qur'an, hadis, ijma', dan qiyas. Karena itu, perbincangan mengenai epistemologi fiqh perempuan sebagaimana yang akan dibahas nanti, akan masuk dalam perbincangan dan konstruk ushul fiqh.

\section{Membincang Epistemologi Fiqh Perempuan}

Epistemologi adalah bagaimana cara ilmu pengetahuan melakukan peng-kajian dan menyusun tubuh pengetahu-annya atau studi filsafat yang membahas ruang lingkup dan batas batas pengetahuan. ${ }^{18}$ Epistemologi merupakan salah satu cabang filsafat ilmu yang membahas tentang "pengetahuan",19 karena perbincangan dalam epistemologi selalu berkai-tan dengan sumber ilmu pengetahuan dan beberapa teori tentang kebenaran.

Para ahli filsafat ilmu menyatakan bahwa dalam kajian epistemologi paling tidak ada tiga problem umum yang men-jadi kajian di dalamnya. Yaitu persoalan hakikat pengetahuan, validitas kebena-ran, serta sumber dan metode untuk memperoleh pengetahuan. ${ }^{20}$ Dengan demikian, tiga problem ini akan dibedah dalam epistemologi fiqh perempuan. Pertama, hakikat fiqh

16 Tâj al-Dîn al-Subkî, Jam' al-Jawâmi' (Surabaya: Pustaka al-Hidayah, t.t.), 32-33

17 Ibid.

18 Dagobert D. Renues, Dictionary of Philosophy, (Toronto, New Jersey: Littlefiled Adam \& Co, 1976), 32.

19 Dua lainnya yang dibahas dalam filsafat ilmu adalah ontologi dan aksiologi. Jika ontologi me-nyangkut tentang hakikat apa yang dikaji atau science of being qua, maka aksiologi adalah untuk apa ilmu yang tersusun tersebut dipergunakan. Ibid., 32.

${ }^{20}$ Harold H. Titus, et.al, Persoalan-Persoalan Filsafat, terj. M. Rasjidi (Jakarta: Bulan Bintang, 1984), 187-188. 
perempuan. Fiqh perempuan, sebagaimana domain fiqh lainnya, harus dipahami sebagai serapan hukum berkaitan dengan perempuan yang bersifat ilahiah (divine law) yang di-kombinasikan dengan hukum hasil tafsiran manusia (made-man law). Ini tidak sama sepenuhnya dengan pendapat Naim yang mengatakan bahwa hukum Islam bukan Islam itu sendiri, melainkan hanya interpretasi para juris terhadap sumber-sumber ajaran Islam. ${ }^{21}$

Gagasan Naim yang menyebut hukum Islam sebagai produk pemaha-man manusia terhadap sumber-sumber Islam pada abad ke-7 hingga abad ke-922 memang benar pada satu sisi, namun mengabaikan fakta aspek divine law yang ikut terlibat dalam pembentukan fiqh perempuan. Padahal fakta divine law men-jadi sesuatu yang memiliki otoritas dalam fiqh perempuan merupakan hal yang tidak terbantahkan. Divine law dalam bentuk Al-Qur'an dan hadis secara faktual benar-benar mewujud sebagai ontologi yang tidak bisa diabaikan dalam wacana fiqh perempuan.

Gagasan an-Naim bertolak bela-kang dengan Taqî al-Dîn alNabhânî yang menyatakan bahwa fakta historis tak perlu dilibatkan dalam pembentukan hukum Islam. Menurut al-Nabhânî, wak-tu dan tempat bukanlah sesuatu yang patut dipertimbangkan, begitu pula hal-nya dengan alasan mendatangkan mash-lahat dan menolak mafsadat. Berdasarkan ini, maka bagi al-Nabhânî, hukum-hu-kum syara' tidak berubah karena peruba-han waktu dan tetap. Hukum syara' tetap tidak berubah walaupun waktu dan tem-pat berubah. ${ }^{23}$

Bagi al-Nabhânî fakta historis lain berupa 'urf dan adatistiadat manusia ju-ga tidak dapat memengaruhi perubahan hukum, karena tradisi bagi pendiri Hizbut Tahrir ini bukan ilat hukum dan bukan dasar suatu hukum. Tradisi adaka-lanya bertentangan dengan syara' dan adakalanya juga tidak. Jika syara' berten-tangan dengan tradisi, syara' harus tegas menghapus tradisi ini, karena salah satu fungsi syariat adalah untuk mengubah tradisi dan adat-istiadat yang rusak yang menjadi penyebab rusaknya masyarakat. Inilah yang

\footnotetext{
21 Abdullahi Ahmed an-Na'im, Dekontruksi Sya-ri'ah: Wacana Kebebasan Sipil, HAM, dan Hubungan Internasional dalam Islam, terj. Ahmad Suaedi dan Amiruddin Arrani, (Yogyakarta: LKiS, 1994), 48.

22 Ibid.

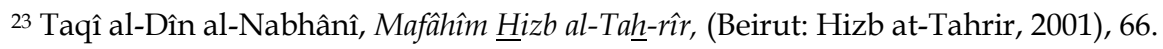


menjadikan tradisi dan adat-istiadat tidak bisa dijadikan dasar maupun 'illat hukum syara'. ${ }^{24}$

Al-Nabhân $\hat{\imath}$ sejatinya hendak me-nempatkan hukum Islam hanya sebagai divine law semata, 25 padahal yang demikian ini adalah suatu hal yang ahistoris. Semata-mata memandang hukum Islam sebagai divine law jelas mengabaikan fakta historis, karena secara de facto hu-kum Islam bergumul dengan realitas yang mengitarinya. Realitas inilah yang selanjutnya menjadi fakta historis dan senantiasa berdialog dengan teks-teks syariat (al-nushîs al-syar'iyyah). ${ }^{26}$

Termasuk pemahaman yang kurang tepat memandang hukum Islam tidak berubah sesuai dengan perubahan ruang dan waktu. Karena dalam hal yang menjadi domain perubahan hukum se-perti muamalah, tentu berubah. Dalam hal yang dipandang sebagai domain tidak adanya perubahan hukum seperti iman pada Allah Swt., kejujuran, keadilan, haji ke Baitullah, dosa besar dengan mencuri, zina, dan sebagainya, tentu tidak boleh ada yang berubah. ${ }^{27}$

Dengan demikian, hakikat fiqh perempuan hasil dialektika antara nash (teks) dengan al-nâs (manusia). Karena itu, watak fiqh perempuan adalah teo-antroposentris. Ada sisi ketuhanan yang tidak bisa ditinggalkan, dan sisi kemanusiaan yang tidak bisa diabaikan. Ini berbeda dengan watak fiqh masa lalu yang cenderung teosentris. Kendati dia-kui masalah faktual yang berbasis prob-lem masyarakat masuk dalam fiqh klasik, namun aura fiqhnya yang teosen-tris lebih terasa dan kelihatan dalam putusan diktum fiqhnya.

Kedua, sumber dan metode fiqh perempuan. Dari segi sumber, fiqh pe-rempuan secara epistemologis merefer pada kondisi riil yang terjadi pada pe-rempuan. Sebagaimana ungkapan Ibn Taymiyah bahwa al-haqî̀ah fì al-a'yân lâ fî al-adzhân (yang hakiki itu ada dalam

24 Ibid.

${ }^{25}$ Dalam pandangan al-Nabhânî, penafsiran terhadap syariat Islam tidak seha-rusnya mengutamakan penyesuaian nash-nash al-Qur'an dengan perkembangan ruang dan waktu. Menurutnya, seharusnya masyarakat yang diubah agar sesuai dengan syariat Islam, bukan sebaliknya. Karena itu, al-Nabhânî menolak kai-dah: Tidak ditolak adanya perubahan terhadap hukum dengan adanya perubahan zaman. Demikian juga kaidah: adat-istiadat dapat dijadikan patokan hukum. Ibid., 10-11.

${ }^{26}$ Hukum Islam adalah dialog antara nash (teks) dan al-nâs (manusia). Keduanya berdialektika menemukan jawaban dalam diskursus ilmu fiqh. Mengabaikan salah satunya, dalam pandangan penulis, akan menyebabkan fiqh sangat "kering".

${ }^{27}$ Khallâf, 'Ilm Ushûl al-Figh, 200. 
realitas, tidak dalam pikiran), demikian juga fiqh perempuan yang lebih tegas menyapa terhadap realitas perempuan.

Dengan demikian, fiqh perem-puan bersumber pada realitas perempuan dan realitas perempuan tidak dapat terwakilkan ataupun tergantikan. Sehingga soal apapun harus ditanyakan terhadap fakta perempuan. Dalam fiqh perempuan, yang berhak bicara harus perempuan dan tidak boleh diwakilkan laki-laki. Fiqh perempuan adalah fiqh yang benar-benar sesuai dengan kehendak, keinginan, dan manifestasi perempuan. Ini bertentangan dengan diktum-diktum fiqh yang selama ini menga-baikan suara perempuan dan bahkan cenderung memarginalkan perempuan. Contoh, akad nikah sebagai kepemilikan suami atas istri, superioritas suami atas istri dalam keluarga, domestifikasi pe-rempuan, nikah di bawah umur, hak ijbar bagi wali, poligami, nusŷuz, dan sebagai-nya. ${ }^{28}$ Ini karena basis epistemologisnya tidak didasarkan pada suara perempuan.

Sekadar menyebut contoh, masa-lah perempuan sebagai korban pemer-kosaan. Perempuan dalam lingkup sistem sosial seringkali disebut sebagai penyulut pemerkosaan. Mereka sering juga diang-gap sebagai biang terjadinya perkosaan, sementara laki-laki pelaku pemerkosaan acapkali tidak dianggap bersalah karena melakukan pemerkosaan. Jika pandangan yang seperti ini dibawa ke dalam fiqh, maka fiqh akan cenderung memarginalkan perempuan. Padahal perempuan sebagai korban pemerkosaan dan kezaliman harus dibela.

Fiqh mazhab Maliki, dalam konteks ini, termasuk fiqh mazhab pembela perempuan. Perempuan dalam kasus perkosaan harus dilindungi, sebagaimana pernyataan Malik berikut ini:

Menurut pendapat kami, orang yang memerkosa wanita, baik masih gadis maupun sudah menikah, jika wanita tersebut adalah wanita merdeka (bukan budak), pemerkosa wajib membe-rikan mahar kepada sang wanita. Sementara itu, jika wanita tersebut ada-lah budak, dia wajib memberikan harta senilai kurang sedikit dari harga budak wanita tersebut. Adapun hukuman dalam masalah ini hanya dibe-rikan pada pemerkosa, sedangkan wanita yang diperkosa tidak mendapat-kan hukuman sama sekali."29

28 Azni Azrai, “Tinjauan Epistemologis Pembaruan Hukum Islam Indonesia Mengenai Kedudukan Perempuan," Conference Proceedings AICIS XII, UIN Sunan Ampel Surabaya, Tahun 2012, makalah, tidak diterbitkan.

${ }^{29}$ Mâlik ibn Anas, Al-Muwattha', (Beirut: Dar al-Fikr, 1989), 273. 
Penegasan Mâlik untuk pelaksa-naan hukum bagi pemerkosa dan tidak ada hukuman bagi korban pemerkosaan adalah terobosan luar biasa yang sangat peduli gender. Karena, bagaimana mungkin, korban harus diberi hukuman karena alasan perempuan merasakan kenikmatan juga. ${ }^{30}$ Sejauh pengamatan penulis, korban pemerkosaan memang benar-benar mengalami trauma dan sakit psikis lain yang tidak mudah diobati. Perasaan inilah yang biasa dialami perempuan.

Senada dengan Mâlik, Sulaimân al-Bâiî al-Mâlikî mengatakan bahwa jika sta-tus wanita yang diperkosa merdeka, ia berhak mendapatkan mahar sewajarnya dari laki-laki yang memerkosanya. Selain itu, pemerkosa juga dijatuhi hukuman had (rajam atau cambuk). Sebab, menurut al-Bâî̂, hukuman had ini terkait dengan hak Allah Swt., sementara kewajiban membayar mahar terkait dengan hak makhluk. ${ }^{31}$ Fiqh mazhab Maliki ini sesuai dengan prinsip melindungi hak-hak perempuan.

Sementara itu, metode fiqh perempuan lebih pada metode yang empiris-historis. Dengan mendasarkan pada fakta-fakta perempuan yang terus berubah, metode yang digunakan adalah metode induktif. ${ }^{32}$ Data-data di lapangan sedemi-kian rupa dikumpulkan dan kemudian disimpukan menjadi kesimpulan paten tentang fiqh perempuan. Karena secara empiris-historis, bisa jadi 'illat hukum berubah-ubah sesuai perkembangan wak-tu dan tempat. Jika 'illat berubah dengan ada atau tidak adanya seperti bunyi kaidah alhukm yadûru ma'a illlatihî wujûdan wa 'adaman, hukumpun juga berubah. Perubahan hukum bukan merupa-kan hal aneh, namun menjadi sebuah keniscayaan dalam perkembangan sejarah.

\footnotetext{
30 Pandangan ini muncul ketika berdiksusi dengan berbagai mahasiswa. Artinya, meski menjadi korban pemerkosaan, mereka tetap dianggap menikmati pemerkosaan tersebut. Padahal korban perkosaan jelas memiliki trauma yang luar biasa. Alissa Wahid mengungkap tiga dampak psiko-logis korban pemerkosaan. Pertama, menyalahkan diri sendiri (self blaming). Kedua, merasa rusak yang oleh karenanya korban pemerkosaan tidak memiliki rasa percaya diri. Ketiga, menarik diri dari lingkungan. www.m.life.viva.co.id (diakses tanggal 16 Juni 2015)

31 Sulayman ibn Khalaf Abu Walid, al-Muntaqâ Syarh al-Muwattha', Cet. I, (Kairo: Dar al-Kitab al-Islamî, 1332), 268.

32 Metode induktif adalah kebalikan metode deduktif. Contoh-contoh konkret dan fakta-fakta diuraikan terlebih dahulu, baru kemudian diru-muskan menjadi suatu kesimpulan atau generalisasi. Pada metode induktif, data dikaji melalui proses yang berlangsung dari fakta.
} 
Pendekatan empiris-historis, menurut Akh. Minhaji, sangat menekankan pengamatan terhadap realitas sekitar yang berkembang di tengah-tengah ma-syarakat, lalu dapat diteruskan dengan identifikasi masalah dan menawarkan alternatif solusi yang dibutuhkan. ${ }^{33}$ Sama dengan objek tema ini, Qodri Azizy, menyebut gagasan pendekatan induktif atau metode ilmiah modern yang tetap berlandaskan pada wahyu. Qodri menye-butnya dengan al-ijtihâd al'ilmî al-ashrî atau modern scientific ijtihad. ${ }^{34}$

Ketiga, validitas hukum dalam epistemologi fiqh perempuan. Dalam pan-dangan penulis, yang dijadikan parameter validitas hukum fiqh perempuan adalah qath'î dan zhannî. Dalam diskursus ushul fiqh, term qath'î dan zhannî masih hangat diperdebatkan.

Secara umum, ada dua terminologi qath'î dan zhannî yang digunakan pada juris Islam. Pertama, qath'î al-tsubît dan zhannî altsubût. Qath'î al-tsubît adalah sumber-sumber dalil yang kuat karena

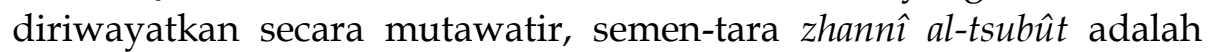
sumber-sumber dalil yang lemah karena tidak diriwa-yatkan secara mutawatir. Al-Qur'an dan hadis mutawatir adalah qath'î al-tsubût, sementara selain dua sumber dalil ter-sebut dikategorikan zhanniy altsubût.35 Kedua, qath'iy al-dalâlah dan zhanniy al-dalâlah. Qath'iy aldalâlah adalah penun-jukan dalil qath'î yang tidak memungkinkan adanya takwil, sedangkan zhanniy al-dalâlah adalah penunjukan dalil zhannî yang memungkinkan adanya takwil. Ulama berbeda pendapat dalam menentukan mana yang qath'iy al-dalâlah dan mana yang zhanniy al-dalâlah. Bisa jadi, seorang ulama menyebut sebuah ayat sebagai qath'iy al-dalâlah, namun ulama lain akan menyebutnya sebagai zhanniy al-dalâlah. ${ }^{36}$

Pada aspek inilah fiqh perempuan diuji validitas dalilnya baik secara wurûd, tsubût, maupun dalâlah-nya. Fiqh perempuan dengan dalil yang zhanniy al-wurûd, misalnya, bisa dimungkinkan ada maknamakna lain yang lebih sesuai dengan mashâlih al-nisấ (kemaslahatan

33 Akh. Minhaji, "Reorientasi Kajian Ushul Fikih" dalam Amin Abdullah et.al, Metodologi Islamic Mazhab Yogyakarta, Cet. I, (Yogyakarta: SUKA Press, 2007), 120.

34 A. Qodri Azizi, Reformasi Bermadzhab: Sebuah Ikhtiar Menuju Ijtihad Saintifik Modern (Jakarta: Teraju, 2003), . 98-99.

${ }^{35}$ Khallâf, 'Ilm Ushûl al-Fiqh, 34-35.

36 Ibid. 
perempuan). Dalil Al-Qur'an dan hadis harus dibaca dalam perspektif keduanya, baik wurûd maupun dalâlah-nya.

Pada ranah epistemologi yang tiga inilah, fiqh perempuan dibangun. De-ngan fiqh perempuan yang baru akan terbentuk sebagai fiqh yang lebih membela kepentingan perempuan. Setidaktidaknya, tidak lagi ada fiqh yang memarginalkan perempuan pada ranah sosial.

\section{Ushul Fiqh Baru untuk Fiqh Perempuan}

Ushul fiqh baru, sebagaimana penulis maksudkan adalah ushul fiqh yang telah diramu sehingga lebih update dan compitable dengan zaman sekarang. Ushul fiqh baru, dengan demikian, lebih merupakan revitalisasi terhadap ushul fiqih klasik yang dipandang tradisional dan tidak relevan dengan kondisi sekarang. Namun ushul fiqh baru juga bukan ushul fiqh yang benar-benar baru de-ngan mengabaikan khazanah klasik yang maha kaya.

Sekurang-kurangnya, ada dua me-tode dalam ushul fiqh klasik yang tetap dapat dipertahankan. Pertama, al-qawâ'id allughawiyyah. Artinya kaidah-kaidah ke-bahasaan tetap dapat digunakan dalam istinbâth al-ahkâm al-syar'iyyah. Kaidah ke-bahasaan seperti lafal musytarak, 'âm, khâsh, mutlaq, muqayyad, dan lain sebagainya adalah kaidah penting dalam mema-hami nush $\hat{\text { sh }}$ syar'iyyah. ${ }^{37}$ Mengabaikan kaidah kebahasaan ini sama dengan me-niadakan kaidah penting dalam memahami nash-nash Al-Qur' an maupun hadis.

Pada aras al-qawấid al-lughawiyyah ini, acuan dalam fiqh perempuan adalah dalil-dalil yang kuat dan pasti (wurûd dan tsubîtnya) serta dengan dalâlah yang pasti juga. Fiqh perempuan tidak bisa ti-dak harus mengacu pada dalil yang dapat dipertanggungjawabkan. Dengan ini, ma-ka rancang bangun fiqh perempuan akan kokoh dan tidak tergoyahkan. Ini berbeda, misalnya, jika dasar-dasar yang digunakan dalam fiqh perempuan adalah dalil-dalil yang wurûd maupun tsubût-nya tidak dapat dipertanggungjawabkan.

Kedua, al-qawâ'id al-tasyri'iyyah. Artinya kaidah-kaidah syariat dalam pem-buatan undang-undang. Paling utama da-lam kaidah tasyri' ini adalah tujuan pe-ngundangan dalam Islam untuk menda-

37 Abû Zahrah, Ushûl al-Figh, 115-196. 
patkan kemaslahatan manusia baik di dunia maupun di akhirat. ${ }^{38}$ Tujuan peng-undangan hukum Islam juga untuk meniadakan madarat bagi manusia. ${ }^{39}$ Bahwa tidak ada yang mendapatkan kemanfaatan dan kemaslahatan hukum Islam, kecuali manusia itu sendiri. Syari`at tidak untuk Tuhan, juga bukan untuk makhluk lain selain manusia. Sebaliknya, syari at hanya untuk kepentingan manusia. Kalau ada sesuatu yang membawa keburukan pada manusia, itu pasti bukan syariat Islam. ${ }^{40}$ Dalam konteks fiqh perempuan, maka syari'at harus berpihak pada perempuan.

Dalam pandangan Wahhâb Khallâf, ada tiga pilar utama yang mensupport kaidah tasyrî́ ini. Pertama, dlarûriyât adalah kebutuhan pokok dan utama yang harus ditunaikan, dan kalau tidak ditunaikan akan membahayakan manusia. Wahhâb Khallâf mencontohkan kebutuhan dlarûriyât laksana bangunan rumah yang menjadi pencegah panasnya terik matahari dan cengkraman musim dingin, meski berupa goa di gunung. ${ }^{41}$ Kebutuhan dlâruriyât ini, misalnya, kewajiban menikah bagi perempuan, yang sine qua none dalam syari'at Islam. Jika tidak ada syari'at menikah ini, maka keberlangsungan manusia (hifd an-nasl) tidak akan terwujud.

Kedua, hajiyât adalah kebutuhan yang harus ditunaikan yang jika tidak ditunaikan akan menjadikan kesulitan dan masyaqqah. Ibarat sebuah rumah, kebutuhan hâjiyât adalah membuat jendela yang bisa dibuka, ditutup, dan menjadi keluar-masuknya udara. Termasuk masyaqqat jika seandainya ada rumah tanpa ada buka tutup jendelanya. Padahal tujuan syari at adalah meringankan dan menghilangkan kesulitan manusia. (QS. al-Maidah 5:6) ${ }^{42}$

Kebutuhan hâjiyât misalnya kebolehan perempuan mencari nafkah di luar rumah dengan niat membantu perekonomian keluarga.

38 Maslahah itu identik dengan al-khayr (kebajikan), al-naf' (Kebermanfaatan), dan al-

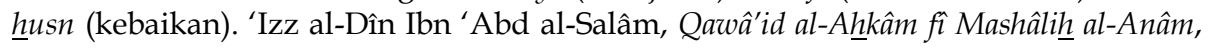
Juz I (Kairo: Maktabah al-Kulliyah al-Azhariyah, 1994), 5.

39 Ibid. Bandingkan dengan Musthafâ Zayd, al-Mashlahah fî al-Tashrî̀ al-Islâmiy wa Najm ad-Dîn al-Thûfî (Beirut: Dâr al-Fikr al-'Araby, 1384 H/1964 M), 221.

40 M.N. Harisudin, Kiai Nyentrik Menggugat Feminisme: Pemikiran Peran Domestik Perempuan Menurut KH. Abd. Muchith Muzadi (Jember: STAIN Jember Press, 2013), 9496. Bandingkan Muhammad Abu Zahra, Ushul al-Figh, (Beirut: Dar al-Fikr al-Araby, 1957), 369.

${ }^{41}$ Khallâf, 'Ilm Ushûl al-Fiqh, 199.

42 Ibid., 200. 
Jika hal demikian ini dilarang, maka akan menyebabkan masaqqat bagi perempuan dan keluarganya. Oleh karena itu, perempuan boleh mencari nafkah dengan catatan mendapat izin dari suami. Ini adalah kebutuhan hâjiyât.

Ketiga, tahsîniyât adalah kebutuhan yang jika tidak ditunaikan akan menyebabkan menyalahi norma, kurang enak dilihat, dan mengurangi harga diri. Ibarat rumah, kebutuhan tahsîniyât adalah perabotan rumah tangga yang menjadi penghias rumah. Dengan kebutuhan tahsîniyât ini, Islam ingin ada perbaikan, keindahan, dan tradisi mereka yang lebih baik. ${ }^{43}$ Contoh kebutuhan ini adalah operasi plastik bagi perempuan dengan maksud dan tujuan mempercantik diri. Hal yang demikian tidak diperbolehkan karena bersifat tahsîniyât. Demikian juga operasi ganti kelamin bagi perempuan normal tidak diperbolehkan karena bersifat tahsîniyât. Berbeda dengan tahsîniyât, dimensi hajiyât dan dlarûriyât dalam fiqh acapkali diperbolehkan. Jika dlarûriyât dibolehkan karena memang dipaksa oleh keadaan, maka dimensi hajiyât dibolehkan karena menempati kedudukan dlarûriyât.

Dengan demikian, ushul fiqh tidak bisa mengabaikan dua hal: kaidah kebahasaan dan kaidah tasyrî́iyyah. Hanya saja, dalam tataran teori, ushul fiqh ini tidak mengapresiasi masalah fiqh perempuan sehingga terlihat cenderung berpihak pada laki-laki, dan sebaliknya abai terhadap perempuan. Artinya, dengan kedua kaidah ini ushul fiqh nampak tidak kritis terhadap realitas yang timpang dan tidak adil terhadap perempuan.

\section{Skema Ushul Fiqh Baru}

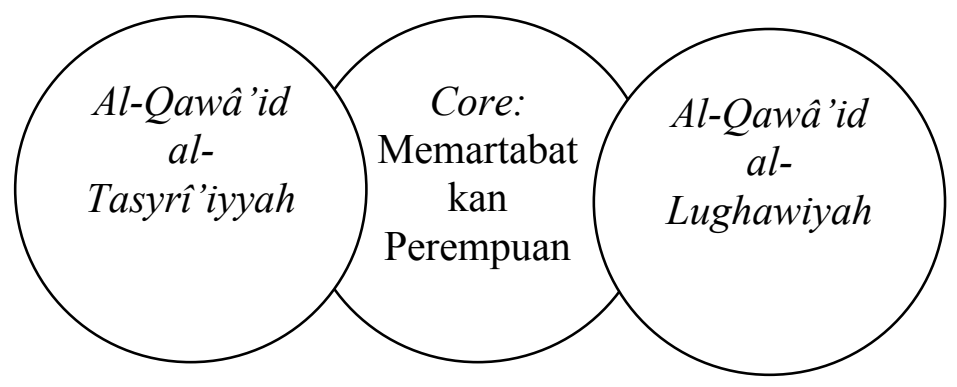

43 Ibid. 
Dalam konteks ini, penulis mengusulkan rancang-bangun ushul fiqh dengan core memartabatkan perempuan. Dengan begitu, core utama ushul fiqh baru adalah ushul fiqh yang memartabatkan perempuan. Dengan menjadikan core ini sebagai dasar dan pilar utama ushul fiqh, istinbâth al-ahkâm untuk menggali hukum-hukum Islam akan terasa keberpihakannya terhadap perempuan. Sehingga diktum fiqh akan lebih jelas keberpihakannya pada kemaslahatan perempuan dan bukan pada yang lain.

Core inilah yang mestinya menjadi jantung dan hati ushul fiqh yang baru. Core ini juga yang menjadi penggerak dan langgam ushul fiqh yang baru, sehingga produk fiqh hasil bentukan ushul fiqh yang baru ini terlihat lebih ramah terhadap perempuan. Karena produk fiqh yang abai terhadap perempuan sesungguhnya bukan soal contentnya, melainkan juga pada aras metodologinya yang tidak berpihak terhadap perempuan.

\section{Penutup}

Keadaan zaman menuntut adanya perubahan epistemogis terhadap fiqh perempuan klasik. Fiqh perempuan klasik, yang juga sering disebut figh al-nisấ, memang harus berubah seiring dengan perkembangan zaman yang tak terelakkan. Jika fiqh perempuan masih mengacu pada realitas klasik dan terus digunakan sekarang, ia akan tidak macth dengan situasi perubahan dan perkembangan di zaman sekarang.

Mereformasi hukum Islam yang cenderung abai terhadap perempuan adalah sebuah sina qua none. Kendati reformasi itu harus urut: pada ranah epistemologisnya, lalu metodologinya, dan terakhir produk fiqh perempuannya. Ketiganya berjalan seiring dengan core utamanya, yaitu memartabatkan perempuan. Dengan demikian, produk fiqh perempuan yang lebih sesuai dengan perubahan tempat dan zaman akan menjadi kenyataan.

\section{Daftar Pustaka}

'Âbidîn, Ibn. Nasyr al-‘Urfi, Juz II. Beirut: Dâr al-Fikr, t.t.

Abdullah, M. Amin. "Paradigma Alternatif Pengembangan Ushul Fiqh dan Dampaknya pada Fiqh Kontemporer", dalam Ainur Rofiq (ed), Mazhab Yogya: Menggagas Paradigma Ushul Figh Kontemporer. Yogyakarta: Ar-Ruzz, 2002.. 
Anas, Malik bin. Al-Muwattha'. Beirut: Dâr al-Fikr, 1989.

Anshâriy, Zakariyâ. Ghâyah al-Wushûl Syarh Lubb al-Wushûl. Semarang: Maktabah al-Alawiyah, t.t.

Arkoun, Mohammed. The Concept of Authority in Islamic Thought, dalam Klaus Ferdinand and Mehdi Mozaffari (ed.), "Islam: State and Society". London: Curzon Press, 1998.

Azizi, A. Qodri. Reformasi Bermadzhab: Sebuah Ikhtiar Menuju Ijtihad Saintifik Modern. Jakarta: Teraju, 2003.

Azni, Azrai. Tinjauan Epistemologis Pembaruan Hukum Islam Indonesia Mengenai Kedudukan Perempuan. Conference Proceedings AICIS XII, Tahun 2012, Makalah, Tidak diterbitkan.

Departemen Pendidikan dan Kebudayaan. Kamus Besar Bahasa Indonesia. Jakarta: Balai Pustaka, 1994.

Harisudin, M. Noor. Ilmu Ushul Fiqh I. Jember: STAIN Jember Press, 2014

-------. Kiai Nyentrik Menggugat Feminisme: Pemikiran Peran Domestik Perempuan Menurut KH. Abd. Muchith Muzadi. Jember: STAIN Jember Press, 2013.

Isfahani, al-Raghib Al-, Mu'jam Mufradât Alfazh al-Qur'ân. Kairo: Dar al-Kitab, al-Araby, tt.

Jawziyah, Ibn al-Qayyim Al-, I'lam al-Muwaqqi'in 'an Rabb al'Alamin, Juz III. Beirut: Dar al-Kutub al-'Ilmiyah, 1993- 1414 H.

Khallâf, 'Abd al-Wahhâb. 'Ilm Ushîul al-Fiqh. Mesir: Al-Haramayn, 2004.

Kulsum, Umi. Risalah Figh Wanita Lengkap. Surabaya: Cahaya Muliah, 2007.

Manzur, Ibn. Lisân al-'Arab, jilid XV. Kairo: Dar al-Hadis, 2003.

Minhaji, Akh. "Reorientasi Kajian Ushul Fikih" dalam Amin Abdullah et.al. Metodologi Islamic Mazhab Yogyakarta. Yogyakarta: SUKA Press, 2007.

Munawir, Ahmad Warson. Kamus al-Munawir Arab Indonesia. Surabaya: Pustaka Progresif, 1997.

Na'im, Abdullahi Ahmed. Dekontruksi Syari'ah: Wacana Kebebasan Sipil, HAM dan Hubungan Internasional dalam Islam. Terj. Ahmad Suaedi dan Amiruddin Arrani, Yogyakarta: LKiS, 1994.

Nabhâniy, Taqiy ad-Dîn Al-, Mafâhîm Hizb al-Tahrîr. Beirut: Hizb atTahrir, 2001. 
Nuruzzaman, et. al. Islam Agama Ramah Perempuan. LKiS: Yogyakarta, 2004.

Renues, Dagobert D., Dictionary of Philosophy. Toronto, New Jersey: Littlefiled Adam \& Co, 1976.

Salâm, 'Izz al-Dîn Ibn 'Abd al-. Qawâa'id al-Ahkâm fî̀ Mashâlih al-Anâm. Juz I. Kairo: Maktabah al-Kulliyah al-Azhariyah, 1994.

Subkiy, Tâj al-Dîn. Jam' al-Jawâmi'. Surabaya: Pustaka al-Hidayah, tt.

Titus, Harold H., et.al. Persoalan-Persoalan Filsafat. Terj. M. Rasjidi, Jakarta: Bulan Bintang, 1984.

Walid, Sulaiman bin Khalaf Abu. Al-Muntaqâ Syarh al-Muwattha'. Cet. I, Kairo: Dar al-Kitab al-Islamy, 1332.

Zahrah, Muhammad Abû. Ushûl al-Figh. Beirut: Dâr al-Fikr al-Arabiy: 1957.

Zayd, Musthafâ. Al-Mashlahah fî al-Tasyrî́ al-Islâmiy wa Najm al-Dîn alThûfìy. Beirut: Dâr al-Fikr al-'Arabiy: 1384 H/1964 M. 